\title{
Aqueous medium-induced micropore formation in plasma polymerized polystyrene: An effective route to inhibit bacteria adhesion
}

Roxana Jijie, ${ }^{1,2}$ Alexandre Barras, ${ }^{2}$ Teodora Teslaru, ${ }^{1}$ Ionut Topala, ${ }^{1}$ Valentin Pohoata, ${ }^{1}$ Marius

Dobromir, ${ }^{3}$ Tetiana Dumych, ${ }^{4}$ Julie Boukaert, ${ }^{4}$ Sabine Szunerits, ${ }^{2}$ Nicoleta Dumitrascu ${ }^{1}$ and Rabah Boukherroub ${ }^{2 *}$

${ }^{1}$ Iasi Plasma Advanced Research Center (IPARC), Faculty of Physics, Alexandru Ioan Cuza University of Iasi, Bd. Carol I No. 11, Iasi 700506, Romania

${ }^{2}$ Univ. Lille, CNRS, Centrale Lille, ISEN, Univ. Valenciennes, UMR 8520 - IEMN, F-59000 Lille, France

${ }^{3}$ Department of Research, Faculty of Physics, Alexandru Ioan Cuza University of Iasi, 11 Carol I Blvd., 700506, Iasi, Romania.

${ }^{4}$ Unité de Glycobiologie Structurale et Fonctionnelle (UGSF), Université Lille 1, CNRS UMR 8576, 59655 Villeneuve d'Ascq, France

*To whom correspondence should be sent: rabah.boukherroub@univ-lille1.fr 


\begin{abstract}
Plasma polymerized styrene (pPS) films were successfully synthesized by means of atmospheric pressure plasma technique, using a mixture of argon gas and styrene vapor. The morphology and film thickness of the pPS films, deposited on 1 min argon plasma pre-treated glass substrates, were smooth and uniform without any visible features across the whole length of the substrates and displayed a water contact angle of $\sim 83^{\circ}$. X-ray photoelectron spectroscopy (XPS) and Fourier transform infrared (FTIR) analysis confirmed the presence of oxygen-containing groups and intact aromatic ring in the pPS coating. The obtained pPS films were stable at least 30 days in air without any visible morphological degradation or chemical changes. However, formation of a topographical pattern with micrometer lateral size and nanometer depth level was observed upon immersion in aqueous media for 72 hours. Micropore formation was believed to originate from the solubility of the low cross-linked oligomers and their subsequent extraction in aqueous media. The influence of the microstructured pPS surface in mediating the attachment of eukaryotic and prokaryotic cells was further investigated. The micro-structured pPS surface influenced the adhesion and proliferation of mammalian cells. Furthermore, we could demonstrate that these films were efficient in the prevention of Gram-negative Escherichia coli (E. coli) and Gram-positive Staphylococcus epidermis (S. epidermis) adhesion and biofilm formation. Importantly, the viability of non-adherent cells and of planktonic bacteria was not affected. Post-coating of microstructured pPS with biocompatible polydopamine did not impact on the antibacterial properties of the surface, suggesting that the polymer topography was the dominant factor. The non-biocidal pPS coating can be useful in applications where microorganism colonization and biofilm formation need to be prevented, such as food packaging and medical equipments.
\end{abstract}

Keywords: Atmospheric plasma polymerization; polystyrene; structured film; anti-biofouling; biofilm. 


\section{Introduction}

The adhesion and retention of unwanted biological species onto surfaces is a serious concern in many areas, including bio-medicine, food packaging and in different domains of industrial engineering, leading to hygienic and economic problems. There is thus an urgent need for new coatings for preventing micro-organism adhesion and colonization of materials.

It is well-established that cell adhesion to a surface proceeds in a number of steps and depends on the surface chemical composition and topography. In addition, compared with planktonic bacteria, bacteria living as a structured community of micro-organisms enclosed in a self-produced polymeric matrix that adheres to a surface, are more resistant to the action of antibacterial agents and consequently difficult to eradicate. ${ }^{1-4}$

In recent years, plasma polymerization of various organic compounds has become particularly attractive for the deposition of thin coatings on complex substrates under dry conditions. ${ }^{4-10}$ Plasma polymerization is a facile and versatile technique that has the advantage to change the surface chemical functionality without affecting the bulk properties of the material. The surface properties like chemical composition, roughness or wettability can be however tailored by tuning the plasma deposition parameters, such as gas composition and/or the reactor geometry. ${ }^{11-14}$ Consequently, plasma polymerization has shown to result in films with cellrepulsive as well as cell-adhesive domains, ${ }^{5}$ hydrophilic alternating with hydrophobic regions, ${ }^{6}$ as well as antifouling and antibacterial character. ${ }^{8,9,13}$ The use of non-thermal atmospheric pressure plasma for the synthesis of thin polymer coatings has become highly attractive as it does not require expensive and time consuming vacuum systems. ${ }^{14-19}$

Like any coating, the long-term stability of plasma polymerized thin coating layers in aqueous media is an important aspect which determines their successful application. The stability of plasma-formed polymers in aqueous media is affected by several factors, such as the degree of polymer crosslinking, film thickness, adhesion strength to the underlying substrate, the nature of the solution where the films are emerged etc. Although a large number of studies have been focused on the synthesis and characterization of plasma polymers for biomedical applications, only a few have investigated their stability in aqueous media and studied eventual bacteria attachment and biofilm formation. ${ }^{8-10,20-22}$ A biodegradable polymer coating synthesized by plasma at atmospheric pressure using a dielectric barrier discharge (DBD) which operates in 
nitrogen or argon - ethyl lactate mixture have been proposed as drug delivery system by Laurent et $a l .{ }^{19}$. Moreover, the ethyl lactate degradable plasma polymer seemed to enable the growth of primary human endothelial cells, therefore showing its potential for vascular applications. Vasilev et $a l .^{8}$ developed plasma polymer films, synthesized from vapor of $n$-heptylamine and post-loaded with silver nanoparticles, as antibacterial coatings without compromising mammalian cell growth. The formation of nanoporous structure in the amine plasma film, upon immersion into aqueous solution, was the underlying mechanism for the excellent loading of the polymer film with Ag NPs. Inhibition of bacteria adhesion and biofilm formation of mixed cultures of Salmonella typhimuriumm, Staphylococcus epidermidis and Pseudomonas fluorescens could be achieved on 12-crown-4-and triglyme-plasma-coated stainless steel surfaces. ${ }^{22}$ Recently, Watkins et al. ${ }^{21}$ reported on the capacity of pulsed plasma formed poly(allyl alcohol) films to impede bacteria adhesion and at the same time allow attachment and proliferation of dermal fibroblast cells.

The present study describes the deposition and characterization of plasma polymerized styrene (pPS) films, synthesized by atmospheric pressure dielectric barrier discharge (AP-DBD), and their application as antibiofouling coatings. In order to establish a correlation between material and plasma properties, the plasma deposition properties were systematically varied. The plasma gas phase was investigated by means of electrical measurements and optical emission spectroscopy, while the pPS coating chemical composition and stability in aqueous media were

assessed by Fourier transform infrared spectroscopy (FTIR), X-ray photoelectron spectroscopy (XPS), scanning electron microscopy (SEM), atomic force microscopy (AFM) and water contact angle (WCA) measurements. The cytotoxicity as well as the anti-fouling properties of the plasma polymerized styrene films were tested against both adherent (HeLa, U-87 MG and HEK) and non-adherent (THP-1) cell lines. It could be shown that pPS films do not interfere with cell attachment and proliferation. The capacity of the coating to prevent biofilm formation was assessed for two bacterial species, the adherent-invasive Gram-negative Escherichia coli strain LF82 (E. coli LF82) and the Gram-positive Staphylococcus epidermis, following $72 \mathrm{~h}$ and $30 \mathrm{~h}$ incubation, respectively.

\section{Experimental}

\subsection{Materials and chemicals}


Styrene (S4972), Thioflavin S (230456), glutaraldehyde solution (G6257), dopamine hydrochloride (H85502), tris buffered saline (T6664), Cell Counting Kit-8 (CCK-8) were purchased from Sigma-Aldrich and used as received.

\subsection{Plasma polymerization of styrene}

Plasma polymerized styrene films (pPS) were synthesized using a dielectric barrier discharge (DBD) in plane parallel configuration, which operates at atmospheric pressure in argon/styrene mixture (Figure 1). The plasma reactor consists of a stainless steel chamber containing two circular parallel plate copper electrodes, deposited as thin films on glass dielectric. It is equipped with two gas lines, one for process gas used to sustain the discharge and other line to transport styrene vapor into plasma volume. The styrene monomer was injected into the reactor using a classic bubbler system that is connected to a shower ring. The $6.5 \mathrm{~cm}$ diameter shower ring contains 12 holes, which allow a uniform vapor distribution in the reactor chamber. The precursor and the discharge environment flow rates were constantly kept at $5 \mu \mathrm{L} \mathrm{min}^{-1}$ and $2.5 \mathrm{~L}$ $\min ^{-1}$, respectively by electronic flow-meters (MKS type $1179 \mathrm{~B}$ ) and a flow controller (MKS type 247). Positive high voltage (HV) pulses with $6 \mathrm{kV}$ amplitude, $2 \mathrm{kHz}$ frequency and $250 \mu \mathrm{s}$ width were applied on the HV electrode. The substrates were placed in the center of the bottom

electrode and the gap between the two electrodes was kept constant at $5 \mathrm{~mm}$. Before deposition, the glass coverslips (12 mm diameter) were immersed in a piranha solution for $10 \mathrm{~min}$ to remove any organic contaminants. Then the piranha treated substrates were rinsed copiously with Milli$\mathrm{Q}$ water and dried under nitrogen flow. 


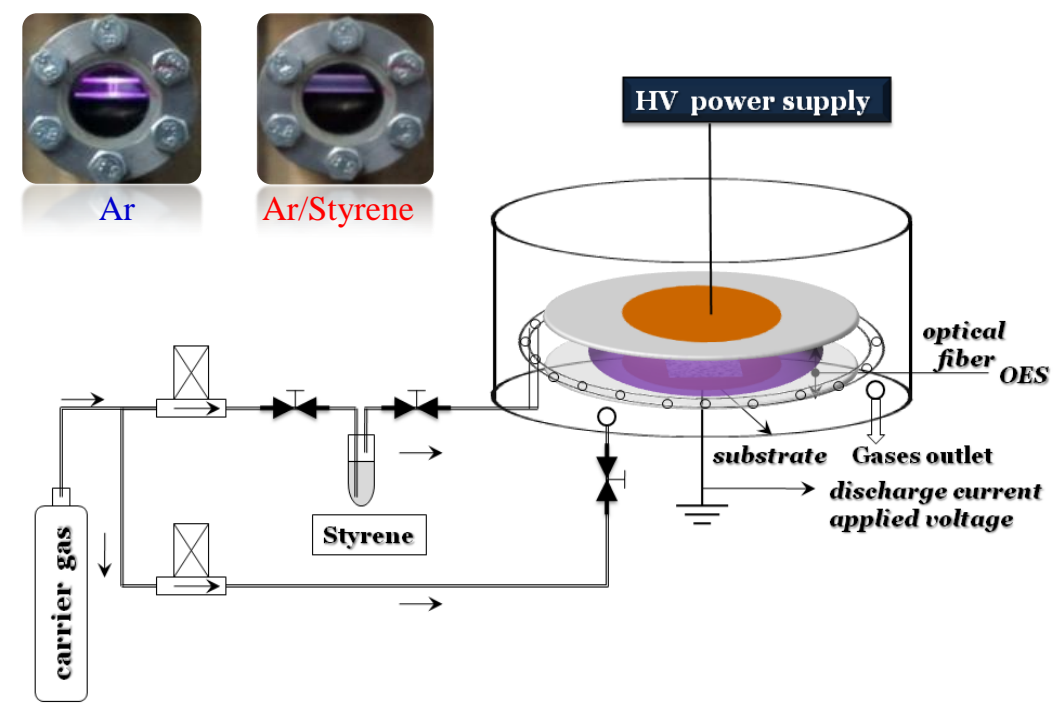

Figure 1. Schematic representation of the plasma polymerization system, including the gas-inlet system and the discharge system.

The deposition time for each film was $10 \mathrm{~min}$. In order to clean and enhance adhesion between the layer and the substrate, the substrates were exposed 1 min to argon plasma before polymer deposition. Samples used for cell culture and bacteria experiments were stored in clean tissue culture polystyrene dishes at ambient temperature. The deposition conditions were optimized and selected in order to obtain films relatively stable in biological media.

\subsection{Plasma diagnostics}

The argon and argon/styrene discharges were investigated by means of electrical measurements and optical emission spectroscopy (OES).

The applied voltage and discharge current waveforms of plasmas were monitored and stored using a high voltage probe (P6015A, Tektronix) and a current probe (6485, Pearson) connected to a digital oscilloscope (TDS5034, Tektronix, $350 \mathrm{MHz}, 5 \mathrm{GSa} / \mathrm{s}$ ). The displacement current $\left(I_{d}\right)$, i.e. the current measured without gas flow, was removed from the total signal.

The optical diagnosis of plasmas (with and without monomers) was performed using a computercontrolled monochromator (Jobin Yvon Triax 550) with a CCD detector (Symphony). The light emitted by the plasma was collected through quartz windows by an optical fiber $(400 \mu \mathrm{m}$ diameter, $24^{\circ}$ acceptance angle, $200-1100 \mathrm{~nm}$ range) guided to the entrance slit of the monochromator. The emission spectra were measured in the $200-900 \mathrm{~nm}$ range. 


\subsection{Coating of pPS with a thin polydopamine layer}

The polydopamine (PDA) deposition was carried out via dopamine (DA) self-polymerization in alkaline $\mathrm{pH}$. Briefly, the pPS films previously soaked in Milli-Q water for $72 \mathrm{~h}$ were immersed for 1 or $4 \mathrm{~h}$ at room temperature into $2 \mathrm{mg} \mathrm{mL}^{-1} \mathrm{DA}$ solution prepared by dissolving DA in 10 $\mathrm{mM}$ Tris- $\mathrm{HCl}$ buffer at $\mathrm{pH}$ 8.5. After incubation, the surfaces were rinsed with Milli-Q water to remove unreacted DA molecules and dried with $\mathrm{N}_{2}$.

\subsection{Characterization}

Fourier transform infrared (FTIR) spectra of plasma polymerized styrene films were recorded using a BOMEM MB-Series 104 spectrometer. Each spectrum was collected by accumulating 5 scans at a resolution of $4 \mathrm{~cm}^{-1}$, in the range of $4000-500 \mathrm{~cm}^{-1}$. The FTIR spectra of pPS deposited on $\mathrm{ZnSe}$ substrates were acquired in the transmission mode. The software GRAMs-AI was employed for measurements and for correction of the background.

X-ray photoelectron spectroscopy (XPS) analysis was performed with a PHI 5000 VersaProbe (Physical Electronics) spectrometer, using a monochromatic Al K $\alpha$ X-ray source $(\mathrm{h} v=1486.7 \mathrm{eV})$, under a vacuum of about $2 \times 10^{-6} \mathrm{~Pa}$ at a photoelectron take-off angle of $45^{\circ}$. Chemical binding information was obtained from high resolution scans of $\mathrm{C}_{1 \mathrm{~s}}$ and $\mathrm{O}_{1 \mathrm{~s}}$ components. The analysis of the spectra was performed using CasaXPS software, with all spectra Shirley background-subtracted prior to fitting. The fitting employed GaussianLorentzian peaks with the fixed G-L percentage $30 \%$.

Atomic force microscopy (AFM) measurements (NT-MDT Solver Pro-M type apparatus) were carried out in ambient air, in the tapping (non-contact) mode, with commercial standard silicon-nitride tips with a radius of approximately 10-15 nm (NT-MDT, NSG03). Scans were repeated on different sites of the samples to check the surface uniformity, under the same conditions in ambient atmosphere. AFM technique was used to visualize and compare the topography of plasma polymer films before and after immersion in aqueous media for $72 \mathrm{~h}$. From AFM images, fast Fourier transform (FFT) and image statistical analysis were performed using Gwyddion and ImageJ, open-source image treatment programs.

The plasma polymer thickness was determined using an interferometric-based technique (Linik MII type). 
Wettability was evaluated by measuring the contact angle between water drops $(2 \mu \mathrm{L})$ and the plasma polymer surface using a horizontal optical microscope with a digital camera (OPTIKAM 4083.BS) connected to a computer. All measurements were made under ambient conditions.

UV-Vis spectroscopic measurements were carried out to monitor the amount of material dissolved during the immersion in Milli-Q water using a dual beam spectrometer (Thermo Scientific Evolution 300) operating at a resolution of $1 \mathrm{~nm}$ in a $1 \mathrm{~cm}$ spectrometric cuvette. The absorbance spectra of the liquid in which pPS film were soaked for different durations ranging from $1 \mathrm{~h}$ to $72 \mathrm{~h}$ were acquired.

\subsection{Cytotoxicity determination of pPS coatings}

\subsubsection{Cell culture and attachment}

Human THP-1 cells were grown in RPMI-1640 supplemented with 10\% fetal-calf serum (FCS) and 1\% penicillin/streptomycin mix; HeLa, U-87 MG and HEK - 293 cells were grown in Dulbecco's Modified Eagle's medium (DMEM, Gibco®) supplemented with $10 \%$ fetal-calf serum (FCS, Gibco®) and 1\% penicillin/streptomycin mix (Gibco®). The cells were maintained at $37{ }^{\circ} \mathrm{C}$ and $5 \% \mathrm{CO}_{2}$ in a humidified incubator.

Direct cytotoxicity testing. Cells were seeded on $1.2 \mathrm{~cm}$ round glass coverslips and plasma polymerized styrene films without (pPS) or with (pPS-72 h) pre-incubation in DMEM medium. Each well was loaded with approximately $1 \times 10^{5}$ THP- 1 cells and $5 \times 10^{4}$ U-87 MG, HeLa and HEK - 293 cells in $500 \mu \mathrm{L}$ of medium.

Indirect cytotoxicity testing. HeLa and U-87 MG were seeded into 96 -well plates $\left(5 \times 10^{3}\right.$ cells $/ 100 \mu \mathrm{L}$ media/well) $24 \mathrm{~h}$ before experiment. Then, the medium was replaced with $100 \mu \mathrm{L}$ of DMEM containing low cross-linked oligomers extracted from pPS matrix for a given time period.

During the incubation, cell adhesion, spreading and growth were assessed using phase-contrast light microscopy. Images of cells were taken at $24 \mathrm{~h}$ intervals over a period of 3 days using a phase-contrast light microscope (Nikon Eclipse TS 100, Nikon - ELWD 0.3/OD75) and a mounted camera. 


\subsubsection{Cytotoxicity assay}

Cell viability was evaluated using the Cell Counting Kit-8 (CCK-8, Sigma Aldrich) assay. Briefly, after $72 \mathrm{~h}$ of incubation in a $5 \% \mathrm{CO}_{2}$ atmosphere at $37{ }^{\circ} \mathrm{C}$, the medium was aspired and the cells washed with $500 \mu \mathrm{L}$ PBS to further remove dead cells debris and remaining growth medium. The incubated surfaces were transferred into a new 24-well cell culture plate. Cells were harvested by trypsination where $50 \mu \mathrm{L}$ trypsin $(0.05 \%) /$ well was spread in a uniform layer and incubated for $5-10 \mathrm{~min}$ at $37{ }^{\circ} \mathrm{C}$ and $5 \% \mathrm{CO}_{2}$ in the humidified incubator. Then the cell suspension was transferred to a 96-well plate (100 $\mu \mathrm{L} /$ well, 5 wells per sample) and incubated for $6 \mathrm{~h}$ at $37^{\circ} \mathrm{C}$ and $5 \% \mathrm{CO}_{2}$. After $6 \mathrm{~h}$ in each well of the plate (+ 2 well with DMEM), $10 \mu \mathrm{L}$ of the CCK-8 solution was added and then the plate was incubated for an additional $3 \mathrm{~h}$ in the incubator. The absorbance of each well at $450 \mathrm{~nm}$ was recorded using a microplate reader (PHERAstar FS, BMG LABTECH GmbH, Germany). The cytotoxicity was expressed as the percent of cell viability to the viability of the control cells, the cells grown on the glass coverslips represented the $100 \%$ viability value. Each condition was replicated for five times; data are presented as means \pm standard deviation.

\subsection{Antibacterial activity determination}

\section{Bacteria culturing attachment and biofilm assay}

A single E. coli LF82 or S. epidermis colony from LB/BHI agar plate was inoculated overnight in LB (Luria-Bertani)/BHI (Brain heart infusion) medium at $37{ }^{\circ} \mathrm{C}$ with moderate shaking. The pre-culture was diluted 50-fold and allowed to continue for another 3-4 h, until the $\mathrm{OD}_{600} \mathrm{~nm}$ had reached 0.6-1. The diluted E. coli $\mathrm{LF} 82$ culture $\left(10^{3} \mathrm{CFU} \mathrm{mL}{ }^{-1}\right)$ was incubated with $12 \mathrm{~mm}$ glass and pPS substrates in 24-well culture plates for $72 \mathrm{~h}$ at $37{ }^{\circ} \mathrm{C}$ to grow biofilm. To assay S. epidermis adhesion and biofilm formation onto surfaces, $50 \mu \mathrm{L}$ of the diluted bacterial culture $\left(\mathrm{OD}_{600}=1\right)$ was plated onto each sample and incubated at $37^{\circ} \mathrm{C}$. After $30 \mathrm{~min}, 1 \mathrm{~mL}$ of BHI medium was added to each well and incubated at $37{ }^{\circ} \mathrm{C}$ for up to $30 \mathrm{~h}$. After incubation, all samples were gently washed with Milli-Q water to remove any non-adherent bacteria.

The samples were sterilized by soaking in a $70 \%$ ethanol solution, rinsed with sterile filtered water and dried in a sterile Petri dish.

\section{Growth Curves}


The samples glass and pPS were placed in 24-well culture plates and incubated for 8 to $24 \mathrm{~h}$ at $37{ }^{\circ} \mathrm{C}$ with $1 \mathrm{~mL}$ Gram-positive or Gram-negative bacteria $\left(10^{3} \mathrm{cfu} \mathrm{mL}{ }^{-1}\right)$ without shaking. To evaluate the effect of oligomers released from pPS matrix on both strains, at selected time intervals, the absorbance was measured at $600 \mathrm{~nm}$. Each condition was replicated for three times; data are presented as means \pm standard deviation.

\section{Scanning Electron Microscopy (SEM)}

The biological samples were fixed with $1 \%$ glutaraldehyde solution for $30 \mathrm{~min}$ in the dark at room temperature. Then the samples were dehydrated in a graded ethanol series of $25 \%, 50 \%$, $75 \%, 95 \%$ and $100 \%(\mathrm{v} / \mathrm{v})$ at 10 min intervals, followed by drying using a vacuum desiccator. Each sample was mounted on stubs and sputter-coated with $5 \mathrm{~nm}$ platinum layer. The samples were examined using a Zeiss Compat Merlin instrument and secondary electron detector at a voltage of $2 \mathrm{kV}$ under high vacuum.

\section{Results and Discussion}

\subsection{Deposition and characterization of pPS coating}

Atmospheric pressure dielectric barrier discharge (AP-DBD) operating in a argon/styrene mixture allows the deposition of macroscopically smooth polystyrene coatings across the whole surface of the glass substrate $\left(113 \mathrm{~mm}^{2}\right)$. The discharge current shape and amplitude observed during the primary and secondary discharges confirm the homogeneous regime of the AP-DBD, necessary to deposit uniform coatings (Figure 2A). In addition, decreasing the discharge current intensity and the emission spectra intensity for Ar/styrene plasma shows that part of the plasma energy is used to induce fragmentation, molecular excitation and plasma polymerization reactions (Figure 2A-B). ${ }^{23-25}$ No nitrogen-containing groups were incorporated in the deposited films, according to XPS and FTIR measurements, although trace nitrogen species were present in the discharge volume, as revealed by the presence of low intensity $\mathrm{N}_{2}$ bands in the emission spectra.

\section{(A)}




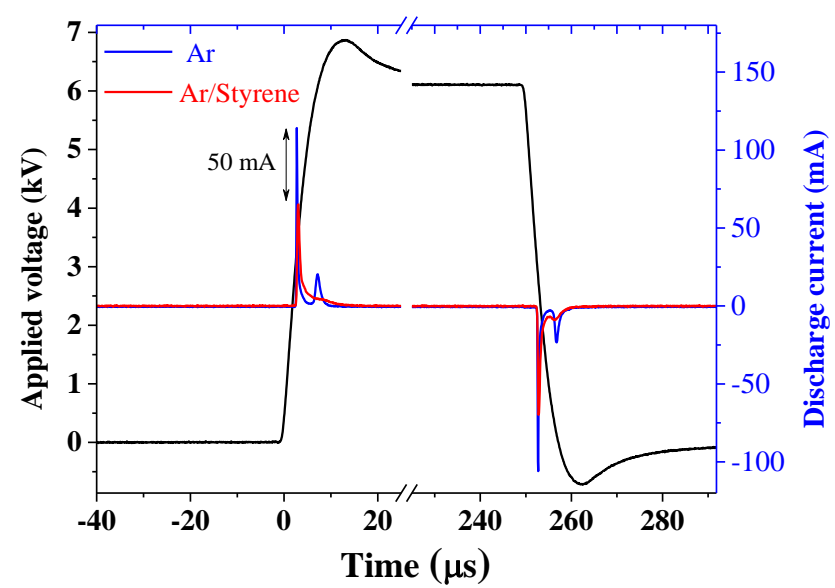

(B)

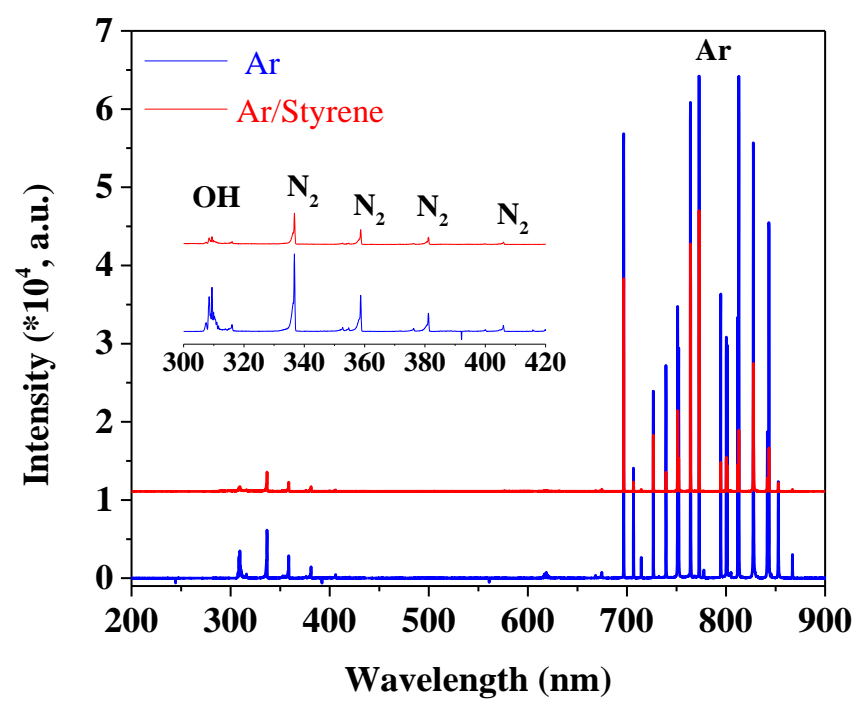

Figure 2. (A) Typical form of the applied voltage and of the discharge current waveforms; (B) The optical emission spectra of the Ar and Ar/styrene discharges.

Since the plasma polymerized styrene films were used as substrates to study the behavior of biological species, a special attention was devoted to their stability in aqueous media. The ageing studies, performed to simulate the storage conditions before the in vitro studies, confirmed that pPS films kept their characteristics even after 30 days under air atmosphere (Figure S1). In addition, air-aged pPS film exposure to aqueous media results in an the extraction of an insignificant amount of oligomers from the polymeric matrix (Figure S2), in agreement with Ref. ${ }^{26}$ Therefore, the post-deposition reactions make the coating more stable, inducing crosslinking between polymer fragments. In our case, the optimum stability was achieved for aged 
plasma polystyrene films deposited using argon/styrene mixture onto 1 min Ar plasma pretreated glass coverslips.

XPS and FTIR results revealed the presence of oxygen functional groups and a partial preservation of the aromatic structure of the monomer. The aromatic ring breakage is confirmed by the disappearance of aromatic C-H bands at 908 and $991 \mathrm{~cm}^{-1}$, the decrease in intensity of the aromatic C-H vibrations, named 'the five aromatic fingers' that appear in the $1665-200 \mathrm{~cm}^{-1}$ and the IR band present in the aliphatic region (Figure 3). It is well known, that plasma polymers are branched and cross-linked different from their counterparts polymerized by conventional methods. The two new peaks that appeared in the spectra at 2964 and $2866 \mathrm{~cm}^{-1}$ suggested that the film is branched. ${ }^{16,25}$ The crosslinking degree is a key parameter, which mediates the behavior of plasma polymers in aqueous media and the literature data revealed that the films synthesized at high powers present a higher stability. ${ }^{13,27-30}$

The presence of oxygen in the pPS network is confirmed by the peaks at 3400 and $1710 \mathrm{~cm}^{-1}$ attributed to hydroxyl and carbonyl stretchings. The oxygen incorporation may originate from two sources, the presence of oxygen and water vapors in the plasma reactor before and during plasma polymerization and from post-oxidation of the coatings exposed to air after plasma deposition. Also, the optical emission spectroscopy confirms the presence of atomic oxygen $(777.4 \mathrm{~nm}$ and $845.2 \mathrm{~nm})$ and hydroxyl radical $(309.1 \mathrm{~nm})$.

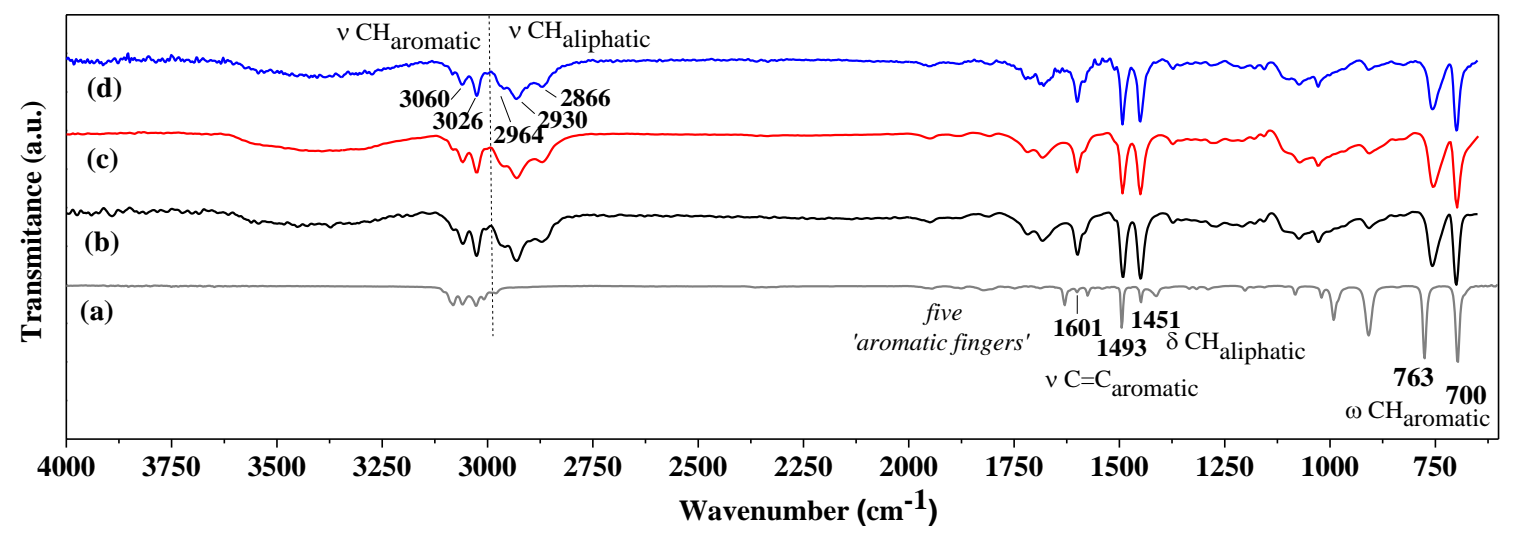

Figure 3. FTIR spectra of (a) styrene monomer, freshly deposited pPS films before (b) and after immersion in MQ-water (c) and LB medium (d) for $72 \mathrm{~h}$. 
The chemical composition of the as-deposited pPS film was analyzed by X-ray photoelectron spectroscopy (XPS), as seen in Figure 4A. The spectrum comprises a main peak attributed to $\mathrm{C}_{1 \mathrm{~s}}$ along with a small peak due to $\mathrm{O}_{1 \mathrm{~s}}$, in good agreement with the FTIR results.

The $\mathrm{C}_{1 \mathrm{~s}}$ high resolution XPS spectrum of the as-deposited PS film can be deconvoluted into three components at $284.6 \mathrm{eV}(\mathrm{C}-\mathrm{C}, \mathrm{C}=\mathrm{C}, \mathrm{C}-\mathrm{H}), 286.3 \mathrm{eV}(\mathrm{C}-\mathrm{O})$ and $291.5 \mathrm{eV}\left(\pi-\pi^{*}\right.$ shake up satellite).

Additionally, the as-deposited pPS coating revealed a moderate wettability with a water contact angle of $84 \pm 2^{\circ}$.

(A)

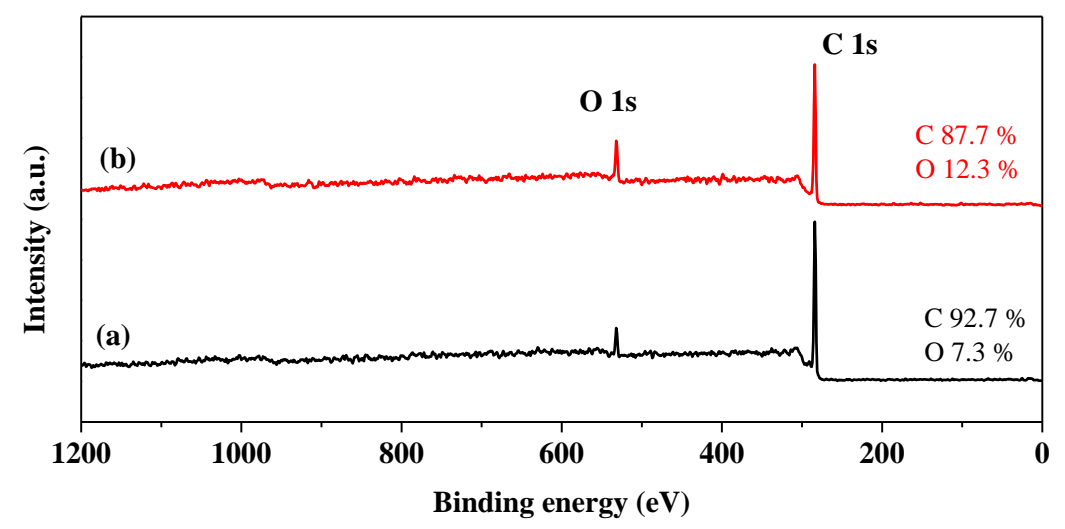

(B)
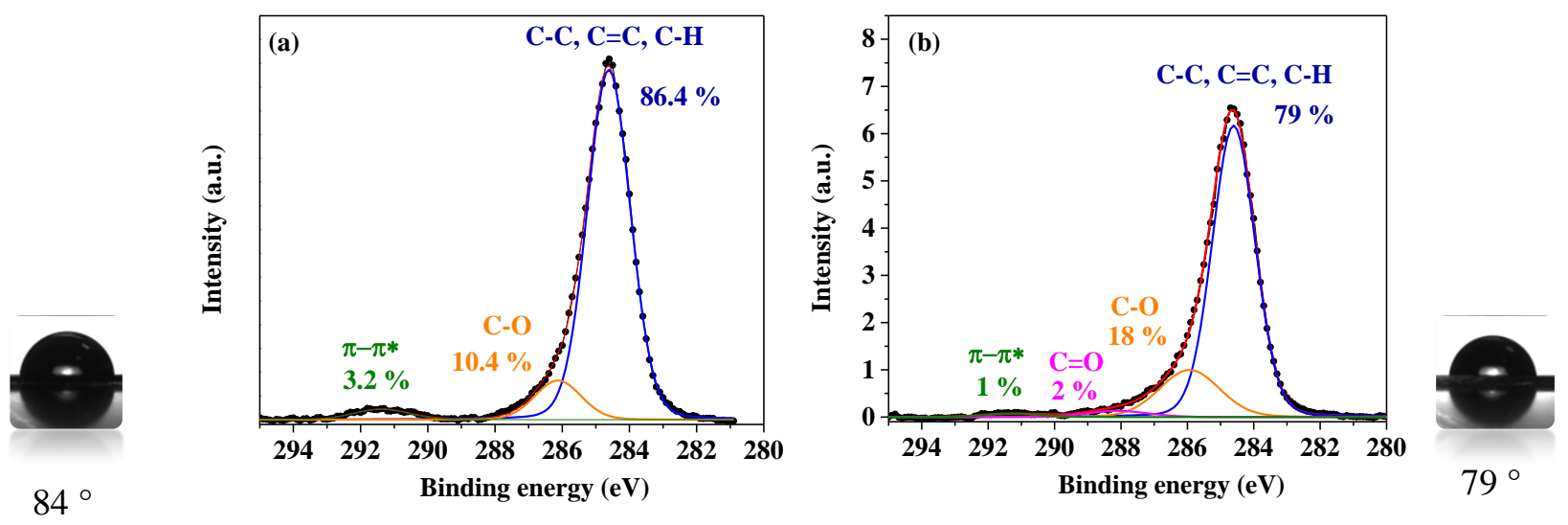
Figure 4. (A) XPS survey spectra and (B) high resolution spectra of pPS film as deposited (a) and after immersion (b) in Milli-Q water for $72 \mathrm{~h}$. Insert: WCA measurements.

\subsection{Stability of the pPS films}

The stability of plasma polymers in aqueous environment is a key parameter that determines their successful application. Due to the random structure of the plasma polymers, several degradation processes could occur: ${ }^{27}$ (i) swelling, a process which involves the diffusion of water into the polymer network, leading to an increase in the film thickness and volume, (ii) homogeneous degradation facilitated by chain cleavage; (iii) diffusion of the oligomers and the formation of a reaction-erosion front at the surface, or (iv) the complete delamination of the film from the substrate.

In general, films with high functional groups density, like carboxylic, hydroxyl or amine groups, can be unstable in liquids while the coatings deposited at high powers are stable. ${ }^{13,27-30}$ Abbas et al. ${ }^{13}$ reported, for example, the dissolution process and the washing out of the uppermost polymer layer. However, a very few studies are devoted to investigate the physicochemical modification induced in plasma polymers upon immersion into aqueous media.

The stability of the pPS films in aqueous solution was studied by immersing the samples in Milli-Q water, tris-buffer solution, DMEM or LB medium for a given time in ambient atmosphere at room temperature or $37^{\circ} \mathrm{C}$. Then, the pPS coatings were dried at $50{ }^{\circ} \mathrm{C}$ for $1-2 \mathrm{~h}$ to evaporate the water. The resulting pPS films were analyzed by FTIR, XPS, AFM, and water contact angle measurements. As can be observed in Figure 3, there is no significant difference between the FTIR spectra of as-deposited films and those of samples immersed in Milli-Q water or LB medium for $72 \mathrm{~h}$, indicating the good stability of these films under the performed conditions.

XPS analysis of the pPS samples after immersion in water for $72 \mathrm{~h}$ showed an increase of the overall oxygen from $7.3 \%$ to $12.3 \%$ (Figure 4A). This is mainly due to an increase of the C-O component at $286.3 \mathrm{eV}$ (Figure 4B) accompanied by a decrease of the $\pi-\pi^{*}$ shake-up satellite peak. Also, it is to be noted that a small contribution of $2 \%$ assigned to $\mathrm{C}=\mathrm{O}$ can be observed after immersion in water for $72 \mathrm{~h}$ (Figure 4B). The increase of oxygen content is responsible of the slight decrease of the water contact angle of the surface from $84^{\circ}$ to $79^{\circ}$. 
In addition, during soaking of the pPS film in aqueous medium, a significant change of the surface morphology from smooth (Figure 5A) to a spatially ordered structure (Figure 5B) could be observed. A similar result was observed by Vasilev et al. $^{26}$ noting that solvent induced formation of pores in $n$-heptylamine plasma polymers, and by Carton et al. ${ }^{31}$ who reported that the surface of plasma polymerized acrylic acid coating after water soaking was significantly modified by a lot of valleys.

In order to gain further insight of the periodicity and symmetry of the void structure, a 2DFFT spectrum was extracted from the AFM image. It clearly shows a multi-dimensional ordering; a polygon-like pattern was observed in the spectrum (Figure 5Ba). ${ }^{32}$ Indeed, immersion into water results in voids uniformly distributed over the entire film surface with micrometer size diameter and nanometer depth level (Figure 5Bb).

(A)
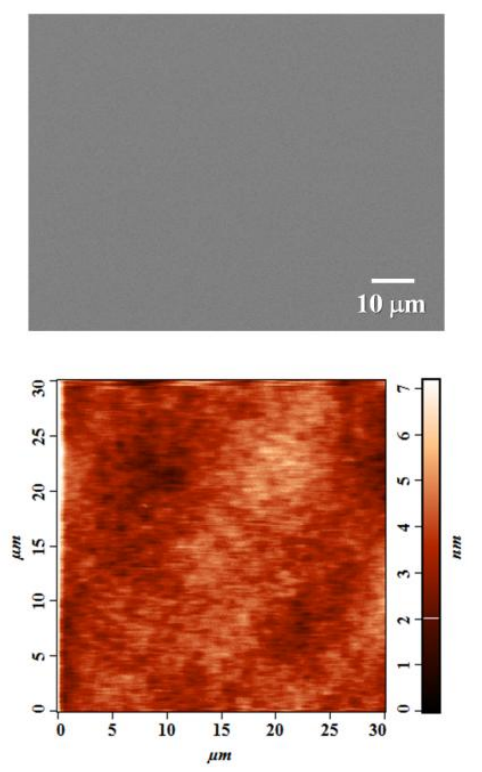

(B)

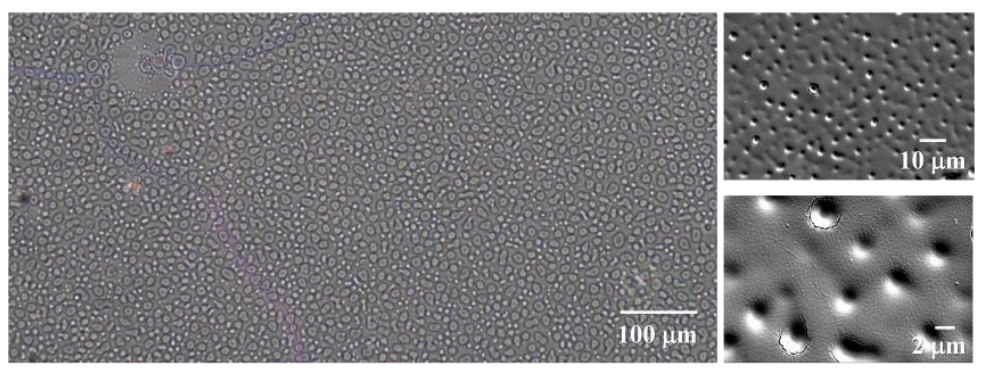

(a)

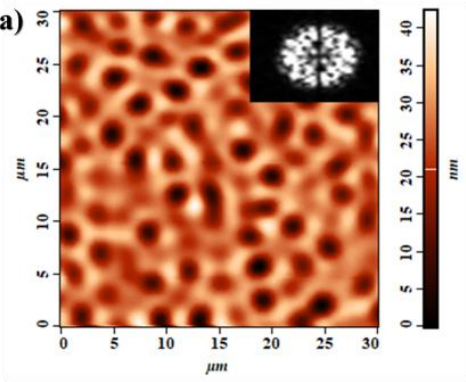

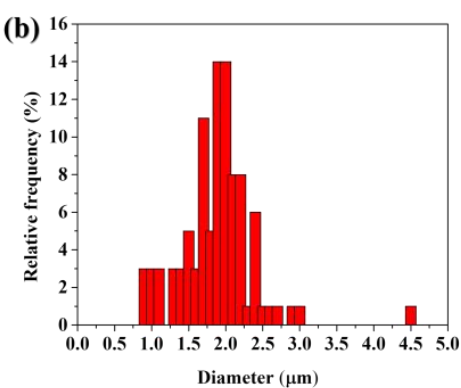

Figure 5. Microscopic images of pPS films (A) before and (B) after $72 \mathrm{~h}$ immersion in aqueous medium. (a) AFM image with an inserted 2D FFT pattern, (b) Distribution of holes' diameter. 


\subsection{Anti-biofouling capacity of the pPS film}

\subsubsection{Influence of surface properties on cell adhesion and viability}

The direct and indirect in vitro cytotoxicity tests of plasma polymerized styrene coatings in DMEM demonstrated that the film is toxic for several types of eukaryotic cells, like HeLa (human cervical carcinoma), U-87 MG (human glioblastoma) and HEK-293 (human embryonic kidney) but non-toxic for HTP-1 (human monocyte type, non-adherent) (Figure 6A). As can be seen in Figure 6A, in the case of adherent cells, after $72 \mathrm{~h}$ of incubation, significant differences in the number of the adherent cells were observed. The low biocompatibility can be related to the coating solubility, topography and chemical composition. It is known that the coating instability can affect protein adsorption and default cell adhesion. Initially, we supposed that the cells attached to the surface are removed with the oligomeric parts of the films in the cell medium, although the surface modification occurs quickly. In order to validate this hypothesis, we seeded cells on both as-deposited and $72 \mathrm{~h}$ DMEM pre-treated pPS coating. The results confirm that the adherent-cells are not able to attach and grow on both samples and the products leached from pPS matrix did not exhibit negative effects on non-adherent cell viability after $72 \mathrm{~h}$ of culture. On the contrary, a significant decrease in cell viability was measured by exposure of two adherent (HeLa and U-87 MG) cell lines to the extracted low cross-linked oligomers from pPS matrix (Figure S3).

(A)

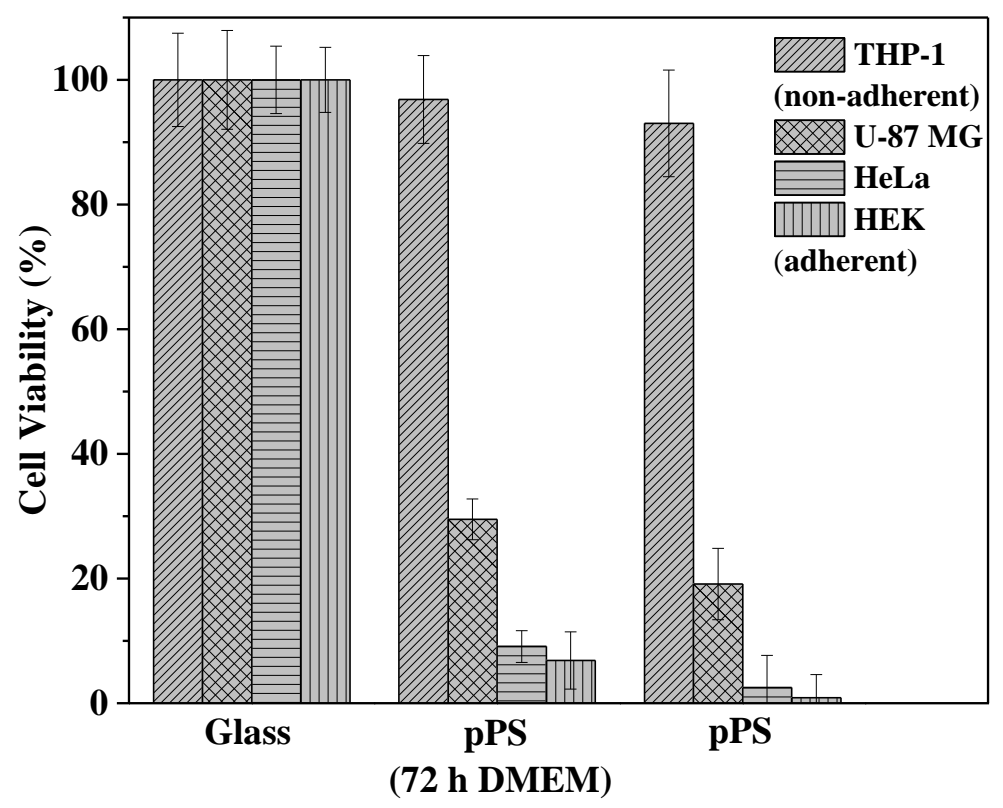


(B)

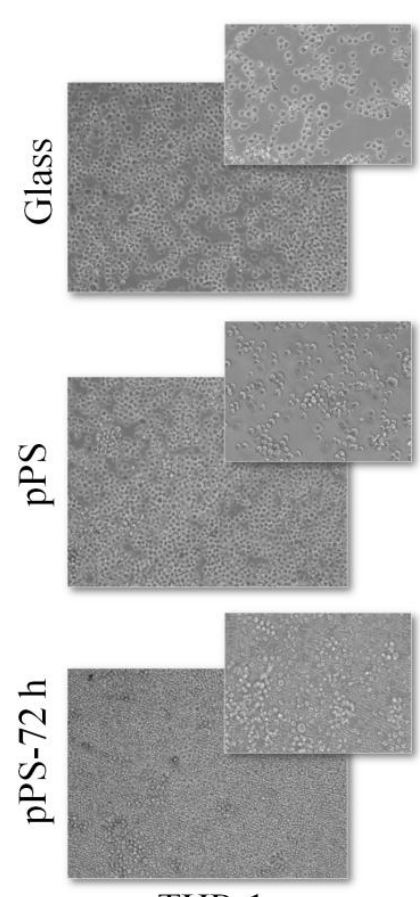

THP-1
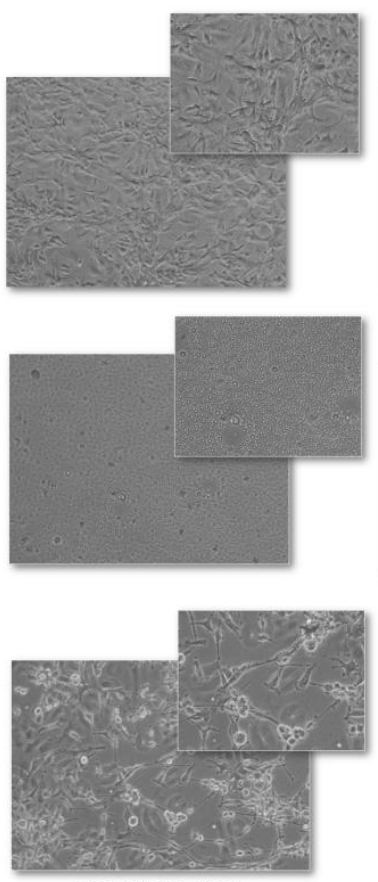

U-87 MG
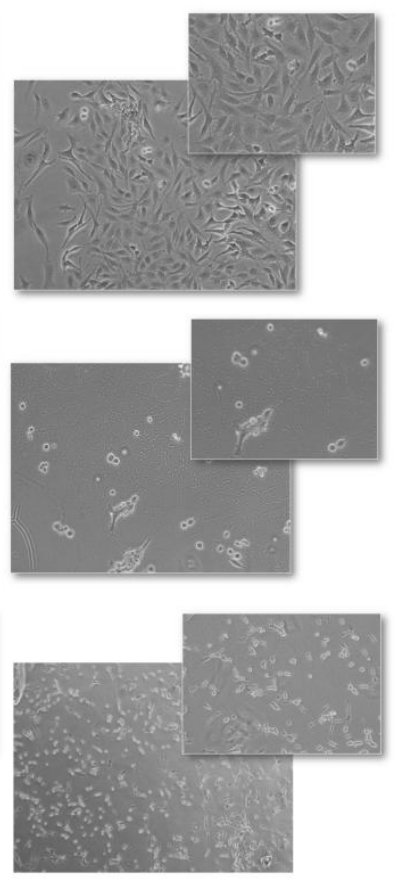

HeLa
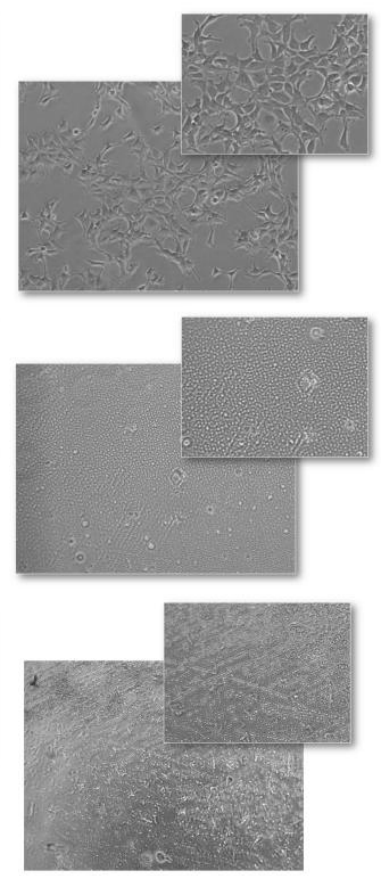

HEK

Figure 6. (A) Relative cell viability and (B) phase contrast microscopy images $(\times 10, \times 20)$ of THP-1, U-87 MG, HeLa and HEK cells after 3 days culture on $12 \mathrm{~mm}$ sterile round glass coverslips and on micro-structured plasma polymerized styrene films.

It is known that an alternative way to control the cell-material response and to reduce the surface cytotoxcity is the immobilization or grafting of biopolymers, such as collagen, chitosan, gelatin, fibronectin. ${ }^{33}$ With the aim to understand whether the cells' response is mediated by film chemical composition, we coated the pPS surface with a polydopamine (PDA) layer. The biocompatibility of polydopamine layer is confirmed by various studies. ${ }^{34-36}$ The PDA deposition was performed via self-polymerization of dopamine in alkaline $\mathrm{pH}$. Briefly, the pPS films were immersed into a dopamine solution ( $2 \mathrm{mg} \mathrm{mL}^{-1}$ in $10 \mathrm{mM}$ Tris-HCl buffer at $\left.\mathrm{pH} 8.5\right)$ for 1 or $4 \mathrm{~h}$ at room temperature and then rinsed with distilled water to remove the unreacted dopamine molecules. WCAs and FTIR measurements confirm the deposition of PDA layer (Figure S4).

As seen in Figure 7, there is no significant difference in HEK cell viability between asdeposited and polydopamine-coated pPS film. Consequently, the results confirm that the adherent cell-repulsive properties of pPS films are mediated by surface topography and by the 
release of oligomers from plasma polymer matrix in the near surrounding solution during the culture.

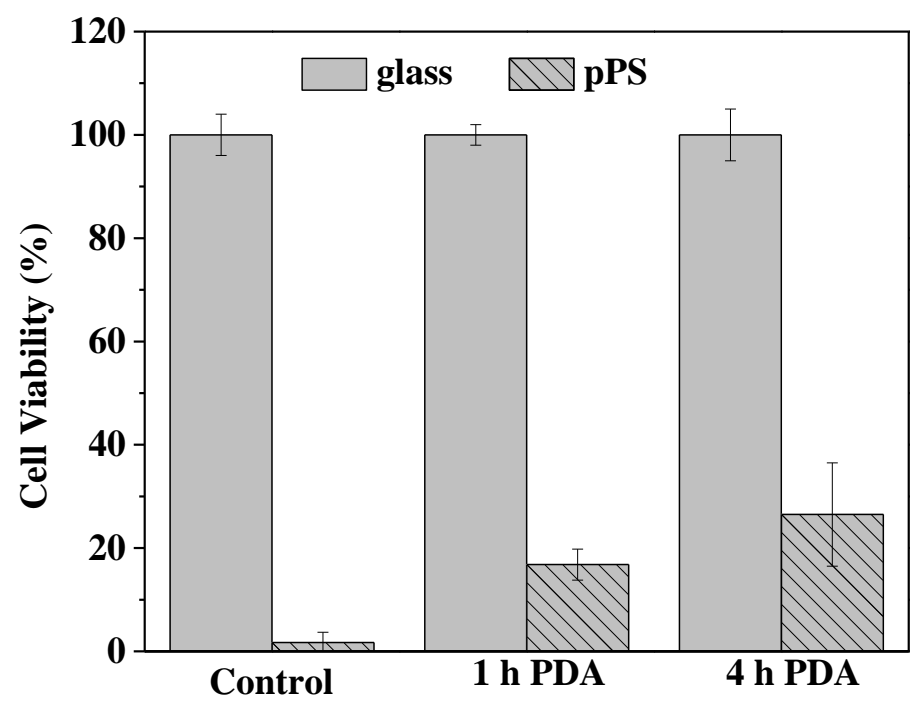

Figure 7. Relative cell viability of HEK cells grown on glass, pPS and PDA-coated substrates after $72 \mathrm{~h}$ of culture.

\subsubsection{Antibacterial activity of plasma polymerized styrene films}

More and more studies report the micro/nano-scale modification of material surfaces as an alternative and a promising new approach to control cell-surface interactions. It is very interesting to note that the multiple properties exhibited by natural surfaces (e.g. plant leaves, shark skin, insect wings, gecko foot and spider silk) have inspired researchers to mimic the surface design to develop antibacterial surfaces. ${ }^{37,} 38$ In most of the studies, it has been demonstrated that bacterial cells prefer to attach and extent on the smoother surfaces than on patterned surfaces and the features' properties in terms of dimensions, organization and chemistry need to be carefully selected in order to control the bacteria arrangement and/or to reduce their extent to the surfaces. ${ }^{39-42}$ For example, Whitehead et al. ${ }^{43}$ reported that $S$. aureus and $P$. Aeruginosa adhered to surfaces defined by regularly spaced pits of 1 and $2 \mu \mathrm{m}$, but not to the surfaces with irregularly spaced pits of 0.2 and $0.5 \mu \mathrm{m}$. Whereas, an aligned attachment of bacterial cells was observed for surfaces with $1.3 \mu \mathrm{m}$ wide and $120 \mathrm{~nm}$ deep channels, ${ }^{44}$ but not for surfaces consisting of a succession of $1.6 \mu \mathrm{m}$ width and $50 \mathrm{~nm}$ depth grooves. ${ }^{20}$ Moreover, an 
engineered surface microtopography, similar to that of the skin of sharks designed on a poly(dimethyl siloxane) elastomer, was found to reduce the attachment and biofilm formation of S. aureus without the need to use bactericidal agents. ${ }^{39}$ Finally, Sirinutsomboon et $a l .{ }^{45}$ showed that surface microstructure geometry and position clearly affect bacterial attachment. They used micro-fabricated silicon surfaces that mimic natural stomata, trichomes and grooves between plant epidermal cells to study the behavior of green fluorescent protein-tagged E. coli O137:H41. The results revealed that trichome surface was less favorable for bacteria adhesion than the stoma or grove surfaces. Independently, it was demonstrated that a cross type feature presented the most significant reduction in bacterial percent area coverage, around $89 \%$, compared with the smooth PDMS control and all other patterned test surfaces. ${ }^{41}$

Compared with others studies, the versatility of our approach arises from the possibility of obtaining features with micrometer size diameter and nanometer depth level distributed over the entire film surface, just by immersion in aqueous medium (Table 1).

Table 1. Selected examples of antibacterial micro/nano-scale patterned surfaces reported recently in the literature.

\begin{tabular}{|c|c|c|c|c|c|c|}
\hline \multirow[t]{2}{*}{ Bacteria strain } & \multirow[t]{2}{*}{ Substrate } & \multirow[t]{2}{*}{ Microstructure } & \multicolumn{3}{|c|}{ Surface features dimensions } & \multirow[t]{2}{*}{ Ref. } \\
\hline & & & $\begin{array}{l}\text { height or } \\
\text { depth }\end{array}$ & $\begin{array}{l}\text { width/ } \\
\text { diameter }\end{array}$ & $\begin{array}{l}\text { spacing } \\
\text { or length }\end{array}$ & \\
\hline S. aureus & PDMS & $\begin{array}{l}\text { Sharklet } \mathrm{AF}^{\mathrm{TM}} \\
\text { topography }\end{array}$ & $3 \mu \mathrm{m}$ & $3 \mu \mathrm{m}$ & $2 \mu \mathrm{m}$ & 39 \\
\hline E. coli & PDMS & 256 circular wells & $5 \mu \mathrm{m}$ & $10 \mu \mathrm{m}$ & $7 \mu \mathrm{m}$ & 46 \\
\hline S. aureus & silicon surfaces & irregular or regular & $0.2 \mu \mathrm{m}$ & $0.2 \mu \mathrm{m}$ & - & 43 \\
\hline C. albicans & & distributed pits & $0.5 \mu \mathrm{m}$ & $0.5 \mu \mathrm{m}$ & - & \\
\hline \multirow[t]{2}{*}{ P. aeruginosa } & & & $1 \mu \mathrm{m}$ & $0.5 \mu \mathrm{m}$ & - & \\
\hline & & & $2 \mu \mathrm{m}$ & $1 \mu \mathrm{m}$ & - & \\
\hline \multirow[t]{5}{*}{ E. cloacae } & PDMS & Cross pillars & 21 & 23 & 5 & 41 \\
\hline & & & 4 & 9 & 2 & \\
\hline & & Hexagonal pits & 3 & 7 & 5 & \\
\hline & & Hexagonal pillars & 3 & 1 & 2 & \\
\hline & & Pillars & 3 & $\begin{array}{c}4,8,12 \\
16 \\
\end{array}$ & 2 & \\
\hline \multirow{3}{*}{$\begin{array}{c}\text { E. coli } \\
\text { O137:H41 }\end{array}$} & silicon surfaces & Trichomes & $18.9 \mu \mathrm{m}$ & $16.9 \mu \mathrm{m}$ & - & 45 \\
\hline & & & $19.1 \mu \mathrm{m}$ & $26.9 \mu \mathrm{m}$ & & \\
\hline & & Grooves & $2.9 \mu \mathrm{m}$ & $2.8 \mu \mathrm{m}$ & $31.4 \mu \mathrm{m}$ & \\
\hline
\end{tabular}




\begin{tabular}{|c|c|c|c|c|c|c|}
\hline & & Stomata & $\begin{array}{l}3.3 \mu \mathrm{m} \\
20 \mu \mathrm{m} \\
20 \mu \mathrm{m}\end{array}$ & $\begin{array}{l}5.2 \mu \mathrm{m} \\
15.9 \mu \mathrm{m} \\
25.7 \mu \mathrm{m}\end{array}$ & $\begin{array}{l}31.9 \mu \mathrm{m} \\
27.6 \mu \mathrm{m} \\
29.5 \mu \mathrm{m}\end{array}$ & \\
\hline E. coli & $\begin{array}{l}\text { PDMS } \\
\text { AGAR }\end{array}$ & Spinach leaves & \multicolumn{3}{|c|}{ spatiallSy periodic microstructures } & 47 \\
\hline $\begin{array}{l}\text { E. coli LF82 } \\
\text { S. epidermis }\end{array}$ & $\mathrm{pPS}$ & $\begin{array}{l}\text { voids uniformly } \\
\text { distributed just by } \\
\text { immersion in } \\
\text { aqueous medium }\end{array}$ & $25.5 \pm 5 \mathrm{~nm}$ & $\begin{array}{c}2 \pm 0.6 \\
\mu \mathrm{m}\end{array}$ & $\begin{array}{c}3 \pm 1.4 \\
\mu \mathrm{m}\end{array}$ & $\begin{array}{l}\text { our } \\
\text { work }\end{array}$ \\
\hline
\end{tabular}

E. coli: Escherichia coli; S. aureus: Staphylocuccus aureus; C. albicans: Candida albicans; P. aeruginosa: Peudomonas aeruginosa; E. cloacae: Enterobacter cloacae; PDMSe: poly(dimethyl siloxane) elastomer; PDMS: polydimethylsiloxane.

Gram-negative Escherichia coli (E. coli) strain LF82 isolated from a patient with Crohn's disease (CD) and Gram-positive Staphylococcus epidermis (S. epidermis) were used to evaluate the anti-biofouling properties of the plasma polymerized styrene films. The E. coli and $S$. epidermis biofilm architecture formed onto the glass slides and the capacity of pPS film to reduce bacterial adhesion and to prevent biofilm formation following $72 \mathrm{~h}$ or $30 \mathrm{~h}$ incubation was visualized using SEM. It can be clearly seen from SEM micrographs (Figure 8A and B) that the adherent bacteria number on the plasma polymerized styrene film was significantly reduced compared to glass slide, where a monolayer of bacteria with a rod-shaped morphology and a thick and dense biofilm consisting of multi-layered spherical bacterial cells can be observed. In addition, the activity of planktonic bacteria was not affected, which correlates well with the result obtained for non-adherent cells (Figure 8C).

(A)

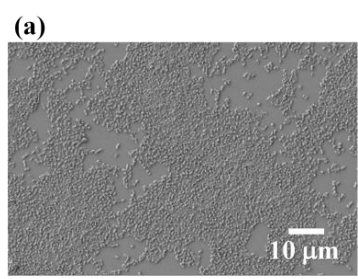

(b)

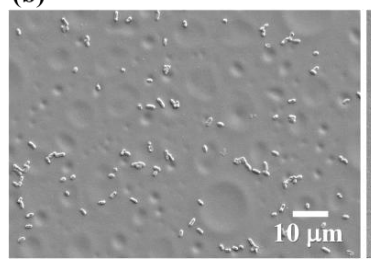

(a)

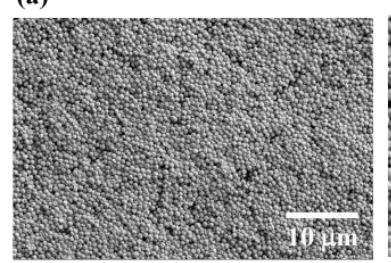

(b)

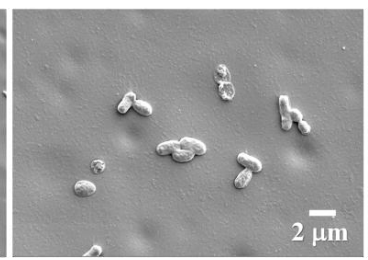

(B)
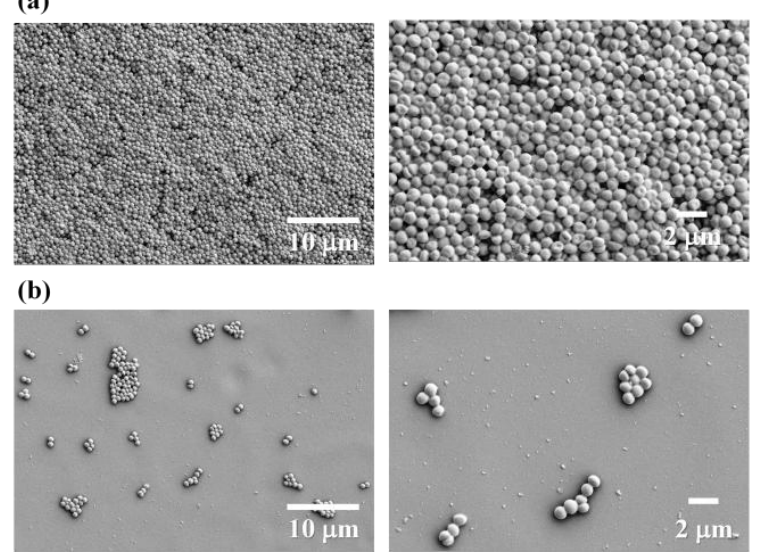
(C)
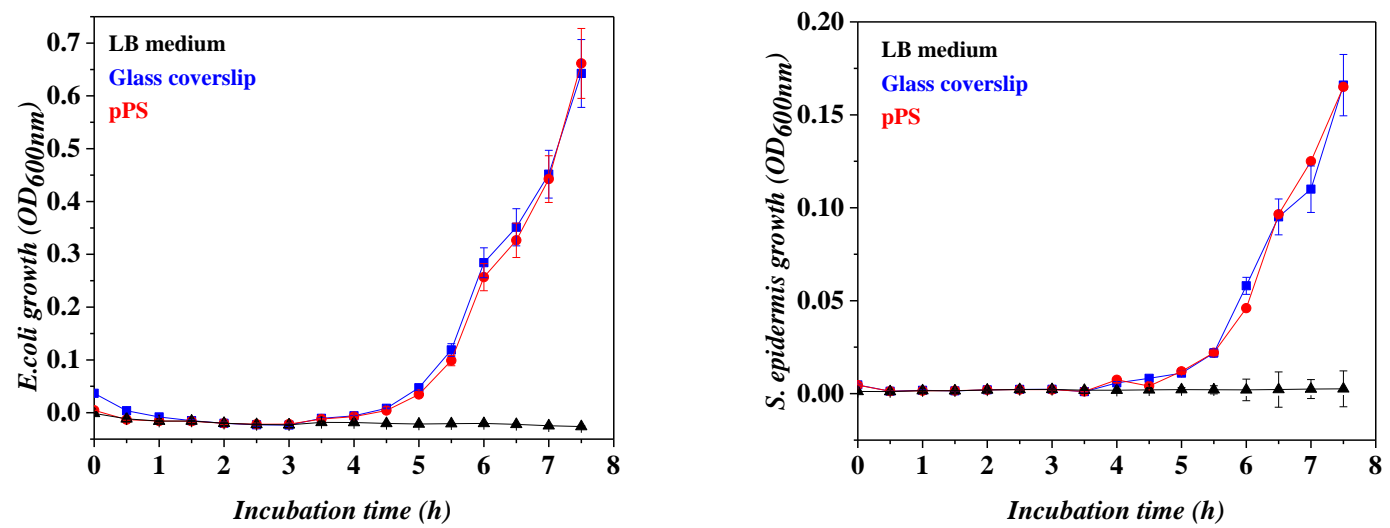

Figure 8. Scanning electron microscopy micrographs of (A) E. coli LF82 following $72 \mathrm{~h}$ incubation and (B) S. epidermis biofilm structure following $30 \mathrm{~h}$ of incubation on (a) glass slide and (b) plasma polymerized styrene surface. (C) Growth curves of bacteria in static condition at $37^{\circ} \mathrm{C}$ in the presence of sterile glass slides and pPS film.

Due to the complexity of bacterial fouling and ablation process, which can be mediated by various factors, it is very difficult to draw a conclusion on the precise mechanism by which the micro-structures inhibit the adhesion and colonization of pPS surface by $E$. coli and $S$. epidermis cells. We assume that these anti-bacterial adhesion properties are due to the presence of oligomers in the near surrounding solution during the culture, an unfavorable surface topography and/or surface chemistry through poor distribution of nutrients required to support the growth of cells.

\section{Conclusions}

This study demonstrated that atmospheric pressure plasma can be successfully applied to deposit thin polystyrene (pPS) films which are stable over a long time span under atmospheric conditions. In contrast, when immersed into aqueous media the morphology changes from a flat surface to a surface with many voids uniformly distributed over the entire film surface with micrometer size diameter and nanometer depth level. The formation of such micropores was assumed to be due to the solubility of low crossed oligomers and their extraction from the film network. This change in topography and the presence of oligomers in the near surrounding solution during culture have a significant role in mediating attachment of adherent eukaryotic 
and prokaryotic cells. The pPS micro-structured surface inhibits the adhesion and proliferation of adherent mammalian cells. It furthermore prevents the adhesion and formation of biofilms of Escherichia coli and Staphylococcus epidermis. Interestingly, the biological activity of nonadherent cells and planktonic bacteria is not affected. Therefore, the non-biocidal pPS coating can be useful for applications where microorganism colonization and biofilm formation are not desired, such as food packaging and medical equipments.

\section{Acknowledgements}

Financial support from the Centre National de la Recherche Scientifique (CNRS), the University of Lille, the Hauts-de-France region, the CPER "Photonics for Society", the Agence Nationale de la Recherche (ANR), the Marie Sklodowska-Curie action (H2020-MSCA-RISE2015, PANG-690836) and Romanian Space Agency (ROSA) under the project STAR CDI ID 349/2014-2016 are acknowledged. We kindly thank Dr. Corentin Spriet, Bio Imaging Center Lille, and Dr. Nicolas Barrois for SEM and fluorescence measurements. We also kindly thank Dr. Kostiantyn Turcheniuk for his support and helpful discussion.

\section{References}

1. J. W. Costerton, P. S. Stewart and E. P. Greenberg, Science, 1999, 284, 1318-1322.

2. L. Hall-Stoodley, J. W. Costerton and P. Stoodley, Nature Rev. Microbiol., 2004, $2,95$.

3. N. Høiby, T. Bjarnsholt, M. Givskov, S. Molin and O. Ciofu, Int. J. Antimicrob. Agents, 2010, 35, 322-332.

4. R. Förch, A. N. Chifen, A. Bousquet, H. L. Khor, M. Jungblut, L. Q. Chu, Z. Zhang, I. Osey- Mensah, E. K. Sinner and W. Knoll, Chem. Vapor Deposition, 2007, 13, 280-294.

5. P. Favia, E. Sardella, R. Gristina and R. d'Agostino, Surf. Coat. Technol., 2003, 169, 707711.

6. V. Sciarratta, K. Sohn, A. Burger- Kentischer, H. Brunner and C. Oehr, Plasma Process. Polym., 2006, 3, 532-539.

7. E. Sardella, L. Detomaso, R. Gristina, G. S. Senesi, H. Agheli, D. S. Sutherland, R. d'Agostino and P. Favia, Plasma Process. Polym., 2008, 5, 540-551.

8. K. Vasilev, V. Sah, K. Anselme, C. Ndi, M. Mateescu, B. r. Dollmann, P. Martinek, H. Ys, L. Ploux and H. J. Griesser, Nano Lett., 2009, 10, 202-207. 
9. A. A. Cavallaro, M. N. Macgregor-Ramiasa and K. Vasilev, ACS Appl. Mater. Interfaces, 2016, 8, 6354-6362.

10. Y. W. Chan, K. S. Siow, P. Y. Ng, U. Gires and B. Y. Majlis, Mater. Sci. Eng. C, 2016, 68, 861-871.

11. M. Chen, T. C. Yang and Z. G. Ma, J. Pol. Sci. Part A: Polym. Chem., 1998, 36, 12651270 .

12. M. Haidopoulos, F. Mirabella, M. Horgnies, C. Volcke, P. A. Thiry, P. Rouxhet and J. J. Pireaux, J. Microscopy, 2007, 228, 227-239.

13. A. Abbas, C. Vivien, B. Bocquet, D. Guillochon and P. Supiot, Plasma Process. Polym., 2009, 6, 593-604.

14. D. Merche, N. Vandencasteele and F. Reniers, Thin Solid Films, 2012, 520, 4219-4236.

15. J. Philipp, A. K. Czerny and C. P. Klages, Plasma Process. Polym., 2016, 13, 509-520.

16. D. Merche, C. Poleunis, P. Bertrand, M. Sferrazza and F. Reniers, IEEE Trans. Plasma Sci., 2009, 37, 951-960.

17. N. D. Boscher, F. Hilt, D. Duday, G. Frache, T. Fouquet and P. Choquet, Plasma Process. Polym., 2015, 12, 66-74.

18. L.-C. Xu and C. A. Siedlecki, Acta Biomater., 2012, 8, 72-81.

19. M. Laurent, J. Koehler, G. Sabbatier, C. A. Hoesli, N. Gherardi and G. Laroche, Plasma Process. Polym., 2016, 13, 711-721.

20. L. Ploux, K. Anselme, A. Dirani, A. Ponche, O. Soppera and V. Roucoules, Langmuir, 2009, 25, 8161-8169.

21. L. M. Watkins, A. F. Lee, J. W. Moir and K. Wilson, ACS Biomater.s Sci. Eng., 2016, 3, 88-94.

22. A. R. Denes, E. B. Somers, A. C. Wong and F. Denes, J. Appl. Polym. Sci., 2001, 81, 3425-3438.

23. I. Topala, N. Dumitrascu and G. Popa, Nuclear Instrum. Methods Phys. Res. Section B: Beam Interactions with Materials and Atoms, 2009, 267, 442-445.

24. M. Asandulesa, I. Topala, V. Pohoata and N. Dumitrascu, J. Appl. Phys., 2010, 108, 093310.

25. M. Asandulesa, I. Topala, V. Pohoata, Y. M. Legrand, M. Dobromir, M. Totolin and N. Dumitrascu, Plasma Process. Polym., 2013, 10, 469-480. 
26. K. Vasilev, L. Britcher, A. Casanal and H. J. Griesser, J. Phys. Chem. B, 2008, 112, 10915-10921.

27. B. Finke, K. Schröder and A. Ohl, Plasma Process. Polym., 2009, 6.

28. R. Morent, N. De Geyter, M. Trentesaux, L. Gengembre, P. Dubruel, C. Leys and E. Payen, Appl. Surf. Sci., 2010, 257, 372-380.

29. A. Michelmore, D. A. Steele, D. E. Robinson, J. D. Whittle and R. D. Short, Soft Matter, 2013, 9, 6167-6175.

30. C. Daunton, L. E. Smith, J. D. Whittle, R. D. Short, D. A. Steele and A. Michelmore, Plasma Process. Polym., 2015, 12, 817-826.

31. O. Carton, D. B. Salem, J. Pulpytel and F. Arefi-Khonsari, Plasma Chem. Plasma Process., 2015, 35, 819-829.

32. X. Xu, J. Wu, X. Wang, M. Zhang, J. Li, Z. Shi, H. Li, Z. Zhou, H. Ji and X. Niu, Nanoscale Res. Lett., 2016, 11, 38.

33. T. Jacobs, R. Morent, N. De Geyter, P. Dubruel and C. Leys, Plasma Chem. Plasma Process., 2012, 32, 1039-1073.

34. M. E. Lynge, R. van der Westen, A. Postma and B. Städler, Nanoscale, 2011, 3, 49164928.

35. S. H. Ku, J. S. Lee and C. B. Park, Langmuir, 2010, 26, 15104-15108.

36. Y. Liu, K. Ai and L. Lu, Chem. Rev., 2014, 114, 5057-5115.

37. J. Hasan, R. J. Crawford and E. P. Ivanova, Trends Biotechnol., 2013, 31, 295-304.

38. J. Hasan and K. Chatterjee, Nanoscale, 2015, 7, 15568-15575.

39. K. K. Chung, J. F. Schumacher, E. M. Sampson, R. A. Burne, P. J. Antonelli and A. B. Brennan, Biointerphases, 2007, 2, 89-94.

40. K. Bazaka, M. V. Jacob, R. J. Crawford and E. P. Ivanova, Appl. Microbiol. Biotechnol., 2012, 95, 299-311.

41. R. Vasudevan, A. J. Kennedy, M. Merritt, F. H. Crocker and R. H. Baney, Colloids Surf. B: Biointerfaces, 2014, 117, 225-232.

42. M. Palacios-Cuesta, A. L. Cortajarena, O. García and J. Rodríguez-Hernández, Polym. Chem., 2015, 6, 2677-2684.

43. K. A. Whitehead, J. Colligon and J. Verran, Colloids Surf. B: Biointerfaces, 2005, 41, 129-138. 
44. C. Díaz, P. Schilardi, R. Salvarezza and M. Fernández Lorenzo de Mele, Langmuir, 2007, 23, 11206-11210.

45. B. Sirinutsomboon, M. J. Delwiche and G. M. Young, Biosystems Eng., 2011, 108, 244252.

46. P. Halder, M. Nasabi, N. Jayasuriya, J. Shimeta, M. Deighton, S. Bhattacharya, A. Mitchell and M. A. Bhuiyan, Biofouling, 2014, 30, 695-707.

47. B. Zhang, Y. Luo, A. J. Pearlstein, J. Aplin, Y. Liu, G. R. Bauchan, G. F. Payne, Q. Wang, X. Nou and P. D. Millner, ACS Appl. Mater. Interfaces, 2014, 6, 12467-12478. 